\title{
Kinetics of Salicylate Elimination by Anephric Patients
}

\author{
David T. Lowenthat, Wifliam A. Briggs, and Gerhard Levy \\ From the Department of Nephrology, Walter Reed Army Medical Center, \\ Washington, District of Columbia 20012, and the Department of Pharmaceutics, \\ School of Pharmacy, State University of New York at Buffalo, New York 14214
}

\begin{abstract}
A BSTRACT The objectives of this research were to determine the kinetics of salicylate elimination in anephric patients and particularly to establish if these patients form the major metabolite of salicylic acid, salicyluric acid, at a normal rate. This investigation was initiated because of conflicting reports concerning the contribution of the kidneys to the formation of salicyluric acid in man. Six patients, $20-44$ yr old, three of whom were anatomically anephric while the other three were physiologically anephric, received an intravenous injection of $500 \mathrm{mg}$ salicylic acid (as sodium salicylate) $/ 1.73 \mathrm{~m}^{2}$ body surface area on an interdialysis day. Serial blood samples were obtained for 12 or $16 \mathrm{~h}$ after injection and the plasma was assayed for salicylic acid, salicyluric acid, total protein, albumin, and creatinine. Detailed pharmacokinetic analysis based on an open, two-compartment linear model revealed no significant differences in apparent volume of distribution and apparent first-order distribution and elimination rate constants between the anephric patients and normal adult subjects. An estimate of salicyluric acid formation rate by the anephric patients, based on the initial rate of increase of salicylurate concentrations in plasma, indicates that the metabolite is formed at a normal rate. These results suggest that the kidneys do not contribute significantly to the formation of salicyluric acid from salicylic acid in man.
\end{abstract}

\section{INTRODUCTION}

The elimination of salicylic acid (SA) ${ }^{1}$ in man involves urinary excretion of the unmetabolized drug and formation of salicyluric acid (SU), salicyl phenolic glucuronide, salicyl acyl glucuronide, and gentisic acid. A

This work was presented to the American Society for Clinical Pharmacology and Therapeutics, 75th Annual Meeting, San Francisco, 28-29 March 1974. An abstract of this research appeared in Clin. Pharmacol. Ther. 15: 211, 1974.

Received for publication 10 April 1974 and in revised form 17 June 1974.

${ }_{1}$ Abbreviations used in this paper: SA, salicylic acid; SU, salicyluric acid. detailed characterization of the pharmacokinetics of salicylate elimination in man has recently been accomplished (1). That study has revealed that two of the major processes of elimination, the formation of $\mathrm{SU}$ and salicyl phenolic glucuronide, are capacity-limited and describable by Michaelis-Menten kinetics, while the other pathways of elimination are apparently first-order, at least in the range of doses studied. As a consequence, the mean plateau level of salicylate in the body increases more than proportionately with increasing dose in the therapeutic dose range (2).

$\mathrm{SU}$, the glycine conjugate of SA, is the major metabolite of SA in man. It may account for more than $70 \%$ of a dose of SA in the low-dose range (3-5). Schachter and Manis (6) have reported that the renal clearance of $\mathrm{SU}$ in man does not exceed the approximate renal plasma flow and that the salicylurate-to-inulin renal clearance ratio observed after administration of salicylate agreed with the clearance data previously determined by others after administration of salicylurate. They concluded that renal synthesis of salicylurate is relatively unimportant. More recently, von Lehmann, Wan, Riegelman, and Becker (7) inferred from "true" and apparent renal clearance ${ }^{2}$ measurements in a single healthy man that approximately $63-71 \%$ of the total amount of SU formed from SA is synthesized by the kidneys. To clarify these conflicting conclusions, we have investigated the elimination kinetics of salicylate in anephric patients, with particular emphasis on an assessment of the rate of formation of SU.

\section{METHODS}

This investigation was carried out on six ambulatory anephric patients with no evidence of liver disease, who are described in Table I. After their informed consent was

\footnotetext{
'The true renal clearance of a drug metabolite is its urinary excretion rate divided by its concentration in plasma at the midpoint of the excretion period during administration of the metabolite itself. The apparent renal clearance of the drug metabolite is determined similarly, except that the drug rather than the metabolite is administered.
} 
TABLE I

Description of Patients

\begin{tabular}{|c|c|c|c|c|c|c|c|c|c|}
\hline Patient & Age & Sex & $\begin{array}{l}\text { Body } \\
\text { surface } \\
\text { area }\end{array}$ & $\begin{array}{l}\text { Type of } \\
\text { anephric** }\end{array}$ & $\begin{array}{c}\text { Blood } \\
\text { urea } N\end{array}$ & $\begin{array}{c}\text { Plasma } \\
\text { creatinine }\end{array}$ & $\begin{array}{l}\text { Total } \\
\text { plasma } \\
\text { proteins }\end{array}$ & $\begin{array}{l}\text { Plasma } \\
\text { albumin }\end{array}$ & Medications \\
\hline & $y r$ & & $m^{2}$ & & $m g / 100 m l$ & $m g / 100 m l$ & $\mathrm{~g} / 100 \mathrm{ml}$ & $\mathrm{g} / 100 \mathrm{ml}$ & \\
\hline B. & 31 & $\mathbf{F}$ & 1.45 & Anatomic & 35 & 10.0 & 6.9 & 3.3 & Amphojel \\
\hline $\mathrm{Br}$. & 20 & F & 1.59 & Anatomic & 48 & 8.5 & 7.7 & 4.0 & Amphojel \\
\hline G. & 31 & M & 1.68 & Anatomic & 45 & 16.5 & 6.4 & 3.2 & Amphojel, folic acid \\
\hline H. & 35 & $\mathbf{M}$ & 1.61 & Physiologic & 40 & 8.0 & 7.0 & 3.8 & $\begin{array}{l}\text { Amphojel, propranolol, } \\
\text { Apresoline }\end{array}$ \\
\hline M. & 43 & M & 1.48 & Physiologic & 79 & 8.2 & 7.3 & 4.0 & $\begin{array}{l}\text { Amphojel, Synthroid, } \\
\text { chloral hydrate, } \\
\text { Aldomet, Surfak }\end{array}$ \\
\hline R. & 44 & $\mathbf{M}$ & 2.1 & Physiologic & 19 & 8.7 & 6.5 & 4.4 & $\begin{array}{l}\text { Amphojel, folic acid, } \\
\text { propranolol, dihydro- } \\
\text { tachysterol multivitamins }\end{array}$ \\
\hline $\begin{array}{l}\text { Normal } \\
\text { values }\end{array}$ & & & & & $10-22$ & $0.7-1.5$ & $6.5-8.0$ & $3.2-5.2$ & \\
\hline
\end{tabular}

* Anatomic anephrics: both kidneys surgically removed due to refractory hypertension, chronic pyelonephritis, or antiglomerular basement membrane antibody-associated glomerular nephritis. Physiologic anephrics: kidneys in situ but nonfunctional (endogenous creatinine clearance $<5 \mathrm{ml} / \mathrm{min}$ ).

obtained, the patients received an intravenous injection of sodium salicylate equivalent to $500 \mathrm{mg} \mathrm{SA} / 1.73 \mathrm{~m}^{2}$ of body surface area. The study was carried out on a day between maintenance hemodialysis treatments, which were performed three times a week. Blood samples were drawn at $-5,2,6,12,30,60,120,300,480$, and 720 or $960 \mathrm{~min}$ after injection.

The concentrations of SA and SU in the plasma were determined by combined colorimetric and fluorometric procedures (8). $0.2 \mathrm{ml}$ plasma, $0.5 \mathrm{ml}$ of $6 \mathrm{~N}$ hydrochloric acid, and $5 \mathrm{ml}$ ethylene dichloride were placed in a $15-\mathrm{ml}$ centrifuge tube, which was shaken vigorously for $1 \mathrm{~h}$ and centrifuged. $4 \mathrm{ml}$ of the ethylene dichloride phase was then transferred to another centrifuge tube and $1 \mathrm{ml}$ of $0.05 \%$ ferric nitrate in $0.0035 \mathrm{~N}$ nitric acid was added. After being vigorously shaken for $5 \mathrm{~min}$ and centrifuged, the aqueous phase was separated and its absorbance was determined at $530 \mathrm{~nm}$ with a Beckman DU spectrophotometer and microcuvettes (Beckman Instruments, Inc., Fullerton, Calif.). $0.5 \mathrm{ml}$ of the aqueous phase was transferred to a fluorometer cuvette and $2.5 \mathrm{ml}$ of $10 \mathrm{~N}$ sodium hydroxide solution and $0.5 \mathrm{ml}$ ethyl alcohol were added. The fluorescence of this solution was determined with a Turner fluorometer, model 111, equipped with a No. 7-60 primary filter and ND $10 \%$ and No. 3 secondary filters (G. K. Turner Associates, Palo Alto, Calif.). Aqueous standard solutions were assayed concurrently. The concentrations of SA and SU were calculated by two simultaneous equations, as described previously (8). The average ( $\pm \mathrm{SD}$ ) apparent concentrations of SA and SU in plasma obtained from the six anephric patients before salicylate injection were 1.27 $( \pm 1.34)$ and $1.17( \pm 1.13) \mathrm{mg} / \mathrm{liter}$, respectively, and all analytical results from the other plasma samples were corrected for these blank values. The recovery of SA and SU was determined by adding known quantities of these compounds to salicylate-free plasma from anephric patients. In the concentration range of $12.5-100 \mathrm{mg} /$ liter (SA) and 5-100 mg/liter (SU), with SA: SU concentration ratios from $4: 1$ to $1: 4$, the recoveries were $99.5 \pm 4.8 \%$ for $S A$ and $95.6 \pm 11.8 \%$ for $S U$ (mean $\pm S D, n=10$ ). The SA plasma concentration data from 2 to $480 \mathrm{~min}$ for each patient were fitted by the digital computer program of Marquardt (9) to obtain the constants $A, B, \alpha$, and $\beta$ for the equation $C=A e^{-\alpha t}+B e^{-\beta t}$, where $C$ is the concentration at time $t$. These constants were used to calculate the rate constants $k_{12}, k_{21}, k_{01}$ and the apparent volumes of distribution $V_{0}$ and $V_{d}$ (area) for an open two-compartment linear system with elimination from the central compartment $(10,11)$. This system may be defined as follows:

$$
k_{12}
$$

Central compartment $\rightleftarrows$ peripheral compartment.

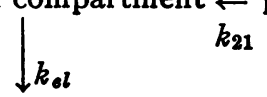

For the determination of the binding of salicylate to plasma proteins, $0.7 \mathrm{ml}$ of plasma obtained by combining equal vol of the 2, 6, and 12-min plasma samples was dialyzed at $37^{\circ} \mathrm{C}$ for $4 \mathrm{~h}$ against an equal volume of isotonic phosphate buffer, $^{8} \mathrm{pH} \mathrm{7.4}$, in rotating Plexiglas cells with a cellophane membrane. Similar determinations were carried out concurrently on plasma samples obtained from seven normal subjects who had not been given salicylate. The phosphate buffer for these experiments contained about $5 \mathrm{mg} \mathrm{SA} / 100 \mathrm{ml}$. Salicylate was added directly to several additional normal plasma samples (rather than to the buffer) to ascertain the attainment of diffusion equilibrium during the dialysis period. $0.5 \mathrm{ml}$ aliquots from the plasma and buffer phases in each dialysis cell were acidified with one drop $6 \mathrm{~N}$ hydrochloric acid, extracted with carbon tetrachloride, and assayed for salicylate (12).

\section{RESULTS}

Fig. 1 shows the time course of salicylate and salicylurate concentrations in the plasma of one of the patients. Similar concentration-vs.-time curves were obtained

${ }^{3} \mathrm{NaH}_{2} \mathrm{PO}_{4} \cdot \mathrm{H}_{2} \mathrm{O}, 0.1805 \mathrm{~g} ; \mathrm{Na}_{2} \mathrm{HPO}_{4} \cdot 7 \mathrm{H}_{3} \mathrm{O}, 1.4305 \mathrm{~g}$; $\mathrm{NaCl}, 0.44 \mathrm{~g}$; and distilled water to yield $100 \mathrm{ml}$ of solution. 
TABLE II

Pharmacokinetic Constants for Salicylate in Anephric Patients

\begin{tabular}{|c|c|c|c|c|c|c|}
\hline \multirow[b]{2}{*}{ Parameter } & \multicolumn{6}{|c|}{ Patients } \\
\hline & Br. & B. & G. & $\mathbf{R}$. & M. & H. \\
\hline A, mg/liter & 123 & 40.8 & 26.1 & 77.3 & 11.4 & 43.8 \\
\hline B, $m g / l i t e r$ & 50.8 & 40.0 & 50.0 & 65.6 & 46.4 & 55.7 \\
\hline$\alpha, \min ^{-1}$ & 0.408 & 0.277 & 0.327 & 0.411 & 0.059 & 0.136 \\
\hline$\beta, * \min ^{-1}$ & 0.00260 & 0.00237 & 0.00263 & 0.00270 & 0.00183 & 0.00159 \\
\hline $\mathrm{k}_{12}, \min ^{-1}$ & 0.281 & 0.136 & 0.110 & 0.218 & 0.0109 & 0.0579 \\
\hline $\mathrm{k}_{21}, \min ^{-1}$ & 0.121 & 0.138 & 0.216 & 0.190 & 0.048 & 0.077 \\
\hline $\mathrm{k}_{01}, \min ^{-1}$ & 0.00879 & 0.00474 & 0.00398 & 0.00584 & 0.00226 & 0.00281 \\
\hline $\mathrm{V}_{\mathrm{o}}$, liter $/ \mathrm{kg}$ & 0.050 & 0.113 & 0.112 & 0.049 & 0.137 & 0.085 \\
\hline $\mathrm{V}_{\mathrm{d}}$ (area), liter $/ \mathrm{kg}$ & 0.168 & 0.226 & 0.170 & 0.106 & 0.170 & 0.150 \\
\hline$t_{i}(\beta), \min$ & 266 & 293 & 264 & 257 & 379 & 436 \\
\hline
\end{tabular}

* The standard error of the $\beta$ values for subjects $\mathrm{Br}$. to $\mathrm{H}$. are $1.3,1.0,2.6,3.0,1.4$, and $1.9 \mathrm{~min}^{-1} \times 10^{-4}$.

for the other patients in this study. The salicylate curves can be described by the biexponential equation $C=A e^{-a t}+$ $B e^{-\beta t}$, where $C$ is the concentration at time $t$ and $A, B$, $\alpha$, and $\beta$ are constants. The values of these constants

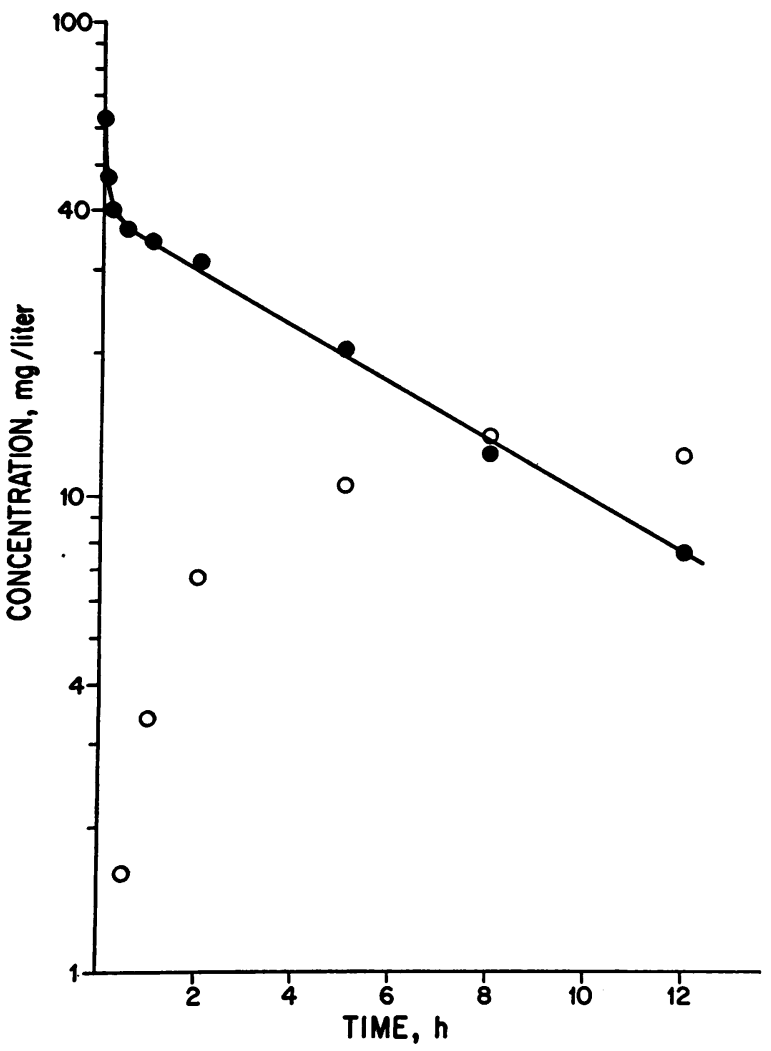

FIGURE 1 Time course of salicylate $(\bullet)$ and salicylurate (O) concentrations in the plasma of patient B. after intravenous injection of sodium salicylate, $500 \mathrm{mg}$ SA equivalent $/ 1.73 \mathrm{~m}^{2}$ of body surface area. The curve for salicylate concentrations was fitted to the data by computer as described in the text. and of the pharmacokinetic constants derived therefrom, including the value of the biologic t $(\beta)$, are listed for each patient in Table II. Four of the patients had $t_{1}(\beta)$ values of less than $300 \mathrm{~min}$, while the other two had a somewhat longer half-life. The average values for the various constants obtained in the patients are listed in Table III together with the values obtained by Rowland and Riegelman (13) in four normal men who received $500 \mathrm{mg}$ SA intravenously. There was no significant difference between the anephric patients and the normal subjects in any of the constants.

The salicylurate concentrations in the plasma increased almost linearly with time during the first few hours and reached a maximum of 13-35 mg/liter, usually at $8 \mathrm{~h}$ after injection of salicylate (Table IV). The initial rate of increase of the plasma salicylurate concentration, determined by a least-squares regression analysis of the 0 -120-min data, was $4.97 \pm 1.69 \mathrm{mg} / \mathrm{liter} / \mathrm{h}$ (mean $\pm \mathrm{SD}$, $n=6)$

Table $\mathrm{V}$ shows the degree of protein binding of salicylate in the plasma of the anephric patients and of seven normal adult subjects (six men, one woman). Since the plasma protein binding of salicylate is concentration dependent, the determinations were made at similar total (free plus protein-bound) concentrations. Salicylate was about $87 \%$ bound in the normal subjects but only about $74 \%$ bound, on the average, in the anephric patients. Thus, the free fraction of salicylate in the plasma of the anephrics was about twice as large as in normal subjects, on the average, in the concentration range studied.

\section{DISCUSSION}

The kinetics of salicylate elimination in man are nonlinear, involving two processes describable by MichaelisMenten kinetics and three others apparently first-order, all in parallel and therefore competing (1). Thus, salicy- 
TABLE III

Comparison of Salicylate Pharmacokinetics in Anephric Patients

and in Healthy Subjects (Means $\pm S D$ )

\begin{tabular}{|c|c|c|c|}
\hline Parameter & Six anephric patients & Four normal subjects* & $\begin{array}{c}\text { Statistical } \\
\text { significance of } \\
\text { difference, } P\end{array}$ \\
\hline$\alpha, \min ^{-1}$ & $0.27 \pm 0.14(0.168) \ddagger$ & $0.19 \pm 0.04(0.182)$ & $>0.3$ \\
\hline$\beta, \min ^{-1}$ & $0.0023 \pm 0.0005(0.0022)$ & $0.0028 \pm 0.0003(0.0028)$ & $>0.1$ \\
\hline $\mathrm{k}_{12}, \min ^{-1}$ & $0.136 \pm 0.100(0.045)$ & $0.0752 \pm 0.0163 \S(0.073)$ & $>0.3$ \\
\hline $\mathrm{k}_{21}, \min ^{-1}$ & $0.132 \pm 0.064(0.101)$ & $0.113 \pm 0.027 \S(0.107)$ & $>0.6$ \\
\hline $\mathrm{k}_{01}, \min ^{-1}$ & $0.0047 \pm 0.0024(0.0039)$ & $0.0048 \pm 0.0007 \S(0.0047)$ & $>0.9$ \\
\hline $\mathrm{V}_{0}$, liter & $5.01 \pm 1.67$ & $5.43 \pm 0.49$ & $>0.7$ \\
\hline $\mathrm{V}_{\mathrm{d}}$ (area), liter & $9.26 \pm 0.72$ & $9.18 \pm 0.87$ & $>0.8$ \\
\hline $\mathrm{t}_{\mathrm{i}}(\beta)$, min & $316 \pm 74$ & $247 \pm 22$ & $>0.1$ \\
\hline
\end{tabular}

* From Rowland and Riegelman, 1968. J. Pharm. Sci., 57 : 1313.

$\ddagger$ Numbers in parentheses are geometric means; all others are arithmetic means.

$\S$ Calculated from the published $A, B, \alpha$, and $\beta$ values.

late levels in the body do not decline apparently exponentially until the amount of drug remaining in the body is very small. This is shown in Fig. 2, a computer simulation based on pharmacokinetic constants obtained from normal adult subjects (1). Nevertheless, the decline of postabsorptive and postdistributive salicylate levels $a p$ pears exponential in a restricted concentration range and it is convenient to describe the plasma concentrationvs.-time curve in such a restricted range by the pharmacokinetic constants of an open, two-compartment linear model. This had been done by other investigators to describe the results of their study of salicylate distribution and elimination in normal subjects under conditions essentially identical to those of this investigation (13). Our study was designed to permit comparison of results with those of the cited investigation on normal subjects, and it was therefore advantageous to analyze the data in the same manner. Consequently, our pharmacokinetic analysis was based on the 0-8-h data, as was the case with the Rowland and Riegelman study (13), and did not include the 12 - or 16 -h concentrations.

TABLE IV

Magnitude and Time of Occurrence of Maximum Salicylurate Concentration in Plasma of Anephric Patients

\begin{tabular}{ccc}
\hline Patient & $\begin{array}{c}\text { Maximum } \\
\text { concentration }\end{array}$ & $\begin{array}{c}\text { Time of } \\
\text { occurrence }\end{array}$ \\
\hline & $m g /$ liter & $h$ \\
Br. & 35.0 & 8 \\
B. & 13.1 & 8 \\
G. & 24.5 & 8 \\
R. & 32.7 & 8 \\
M. & 17.7 & 12 \\
H. & 16.1 & 8 \\
\hline
\end{tabular}

The range of salicylate levels encompassed by the pharmacokinetic analysis is indicated by the stippled square in Fig. 2. Also shown in that figure are points representing the $1,2,5$, and $8-h$ blood withdrawal times. These points can be fitted to a straight line with the slope equivalent to a half-life of $300 \mathrm{~min}$ in normal subjects. It should be clearly understood that the pharmacokinetic "constants" obtained in the manner described here only describe the time course of salicylate concentrations in the range studied, and do not apply to concentrations above or below this range.

The metabolic fate of salicylate is quantitatively very dependent upon dose and urine $\mathrm{pH}$ (5). In normal subjects, $66 \%$ of the dose used in this study will, on the average, be converted to salicyluric acid and less than $5 \%$ will be excreted in unmetabolized form (5).

Thus, the absence of renal excretory capacity should have a negligible effect on the time course of salicylate elimination," all else being the same. If, however, as proposed by von Lehmann et al. (7), from 60 to $70 \%$ of salicylurate is formed in the kidneys, then the absence of kidneys should have a pronounced effect on the kinetics of salicylate elimination. One would expect an approximately twofold increase in the apparent halflife of salicylate under these conditions.

The results of our study show no statistically significant difference between the anephric patients and normal subjects in any of the pharmacokinetic parameters of salicylate elimination. The mean apparent half-life of salicylate in the anephrics, $316 \mathrm{~min}$, may be compared to a mean of $300 \mathrm{~min}$ (Fig. 2) and $247 \mathrm{~min}$ (Table III), respectively, for two groups of normal adult subjects. The apparent volume of distribution for

\footnotetext{
"Drug "elimination" refers to the disappearance of the drug itself from the body, whether or not the drug metabolites are still present.
} 
salicylate, $V_{\alpha}$ (area), is practically identical in the anephrics and normal subjects (Table III). Lack of body weight data for the normal subjects (13) prevented calculation of their relative $V_{d}$ (area), but the relative $V_{d}$ (area) in the anephrics (Table II) is in the same range as that obtained in other studies on normal adults given similar doses of salicylate $(14,15)$. The plasma concentration of salicylurate in the anephrics (Table IV) is considerably higher than in subjects with normal renal function. The salicylurate concentration in the plasma of normal subjects receiving $7.2 \mathrm{~g}$ aspirin/day for a wk (which will cause them to synthesize salicylurate at a near maximum rate) was $1.88 \pm 0.51$ $\mathrm{mg} /$ liter (mean $\pm \mathrm{SD}, n=8$ ) (16). This difference is undoubtedly due to the absence of renal excretory function in the anephrics, since SU is ordinarily eliminated almost completely by renal excretion without further biotransformation (17).

The anephric patients showed considerably less plasma protein binding of salicylate than did normal subjects (Table V). This cannot be ascribed to lower plasma albumin concentrations, since these were in the normal range (Table I). Similar results were recently obtained by Andreasen (18) in surgical patients with acute renal failure and are also found with many other drugs $(19,20)$. The decreased plasma protein binding of salicylate in anephrics has apparently little or no effect on their $V_{d}$ (area) for salicylate, probably because the drug is not very highly bound even in normal subjects.

An estimate of the initial rate of SU formation by the anephric patients can be obtained from the initial rate of increase of their plasma salicylurate concentration multiplied by the apparent volume of distribution of salicylurate. The latter is about 0.138 liter $/ \mathrm{kg}$ in normal sub-

\section{TABLE V}

Plasma Protein Binding* of Salicylate in Normal Subjects and in Anephric Patients

\begin{tabular}{|c|c|c|c|c|c|}
\hline \multicolumn{3}{|c|}{ Normal subjects, total SA } & \multicolumn{3}{|c|}{ Anephric patients, total SA } \\
\hline Subject & Concn & $\%$ free & Patient & Concn & $\%$ free \\
\hline \multicolumn{3}{|c|}{$m g / 100 m l$} & \multicolumn{3}{|c|}{$\mathrm{mg} / 100 \mathrm{ml}$} \\
\hline B. & 4.80 & 12.7 & H. & 7.98 & 19.0 \\
\hline L. & 5.70 & 12.4 & M. & 4.43 & 22.8 \\
\hline N. & 5.65 & 13.7 & B. & 4.22 & 26.1 \\
\hline S. & 4.72 & 15.1 & $\mathrm{Br}$. & 5.76 & 31.2 \\
\hline T. & 4.66 & 12.6 & G. & 4.69 & 22.8 \\
\hline G. & 4.71 & 14.4 & $\mathrm{R}$. & 6.99 & 34.0 \\
\hline R. & 4.95 & 13.5 & & & \\
\hline Mean & 5.03 & 13.5 & & 5.68 & 26.0 \\
\hline
\end{tabular}

* Equilibrium dialysis against isotonic phosphate buffer, pH 7.4, at $37^{\circ} \mathrm{C}$.

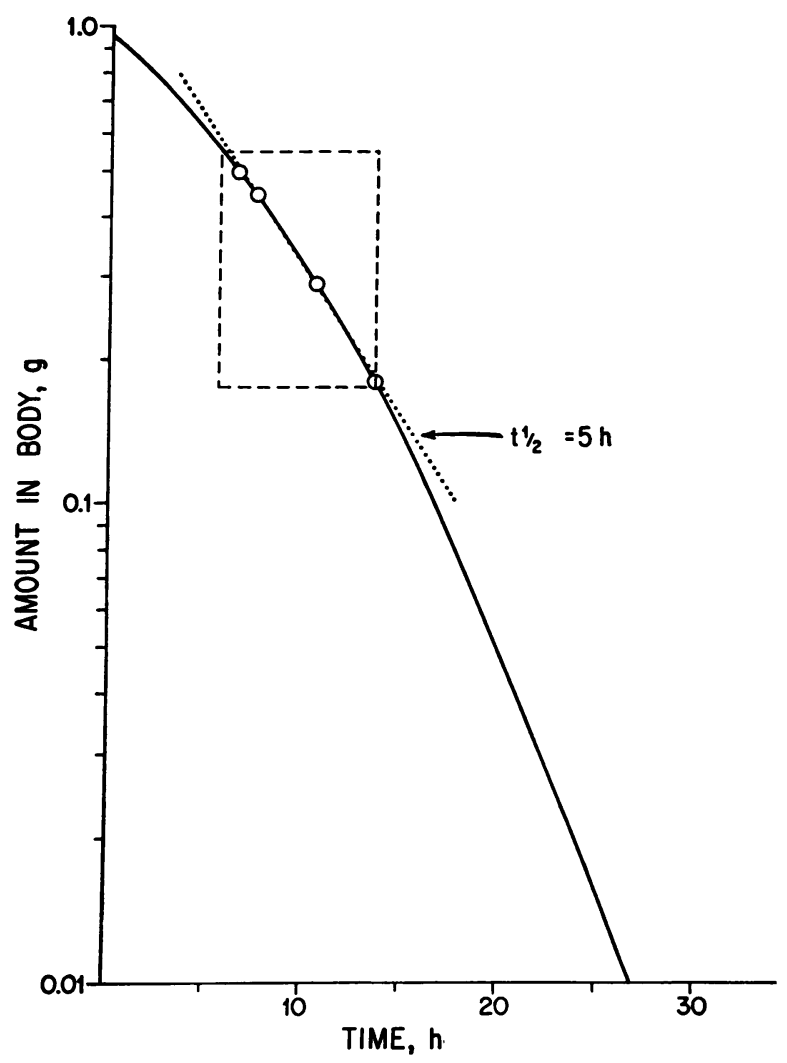

Figure 2 Time course of salicylate elimination by normal adult subjects, based on pharmacokinetic constants from reference 1 . The stippled square shows the range of salicylate levels encompassed by the data obtained in this investigation and the circles indicate the $1,2,5$, and 8-h blood sampling times. The dotted line was fitted to these points.

jects ${ }^{5}$ and can be expected to be similar (and certainly not smaller) in the anephrics. Thus, $4.97 \mathrm{mg} / \mathrm{liter} / \mathrm{h} \times$ $0.138 \mathrm{liter} / \mathrm{kg} \times 67.8 \mathrm{~kg}=46.5 \mathrm{mg} / \mathrm{h}$, where the rate term is the average initial rate of increase of the salicylurate concentration in the plasma and the weight term is the average body weight of the anephric patients. The comparable value for normal adults, calculated by the Michaelis-Menten equation with previously obtained values for $V_{\text {mas }}$ and $K_{m}$ (1) and a mean body level of $475 \mathrm{mg} \mathrm{SA}$ is $50 \mathrm{mg} / \mathrm{h}$, or $51 \mathrm{mg} / \mathrm{h}$ when corrected for the difference in body weight of the two groups. Thus, the anephric patients apparently synthesize salicylurate at a normal rate.

The results of this investigation support the conclusions by Schachter and Manis, who expressed the view that renal synthesis of salicylurate in man is rela-

'This is calculated from the data in references 6 and 17, by the equation: apparent volume of distribution = rate of formation of salicylurate/(plateau concentration of salicylurate-salicylurate elimination rate constant). 
tively unimportant (6). Our results are not consistent with those of von Lehmann et al. (7), who inferred from their data on a single normal subject that the kidneys account for approximately $60-70 \%$ of the salicylurate formed. The investigation by von Lehmann et al. suffered from certain methodological deficiencies, so that their conclusions must be considered as tentative and requiring further experimental work under more appropriate conditions (21). It is possible also that the single subject studied is not representative of the population or that the pharmacokinetic model employed is inadequate. There is no evidence, however, to support these speculations. It is also possible in theory that the anephrics developed an increased capacity for salicylurate formation in the liver or that the greater driving force of the higher fraction of free drug in the circulation (due to decreased protein binding) causes an increase in the apparent biotransformation rate constants. Again, there is no evidence to support these possibilities. Thus, the available evidence favors the conclusion that the kidneys do not contribute significantly to the formation of salicylurate from salicylate in man.

The results of this investigation should not be interpreted as an indication that the kinetics of salicylate elimination by anephric patients will be normal at doses higher than the dose used here. Due to the limited capacity of the salicylurate and salicyl phenolic glucuronide formation pathways, renal excretion of unmetabolized drug becomes increasingly important at higher doses and may, depending on urine $\mathrm{pH}$, account for more than one-half of the dose in subjects with normal renal function. The other apparently linear elimination processes, salicyl acyl glucuronide and gentisic acid formation, will also become quantitatively more important. They contribute so little to the elimination of the $0.5 \mathrm{~g}$ dose used in this study (6) that it cannot be established from the results of this investigation if these processes are normal or impaired in anephrics. Thus, anephrics eliminate small doses of salicylate at a near normal rate but it is to be expected that large doses will be eliminated more slowly than in normal subjects, due to the absence of the renal excretory pathway.

\section{ACKNOWLEDGMENTS}

Mrs. R. Koysooko, Mrs. J. A. Procknal, and Mr. David M. Soda provided competent technical assistance. We thank the patients who participated in the investigation for their cooperation.

This investigation was supported in part by Research Grant GM 19568 from the Institute of General Medical Sciences, National Institutes of Health.

\section{REFERENCES}

1. Levy, G., T. Tsuchiya, and L. P. Amsel. 1972. Limited capacity for salicyl phenolic glucuronide formation and its effect on the kinetics of salicylate elimination in man. Clin. Pharmacol. Ther. 13: 258-268.

2. Levy, G., and T. Tsuchiya. 1972. Salicylate accumulation kinetics in man. N. Engl. J. Med. 287 : 430-432.

3. Levy, G. 1965. Pharmacokinetics of salicylate elimination in man. J. Pharm. Sci. 54: 959-967.

4. Leonards, J. R., and G. Levy. 1965. Absorption and metabolism of aspirin administered in enteric-coated tablets. J. Am. Med. Assoc. 193: 99-104.

5. Tsuchiya, T., and G. Levy. 1972. Biotransformation of salicylic acid to its acyl and phenolic glucuronides in man. J. Pharm. Sci. 61: 800-801.

6. Schachter, D., and J. G. Manis. 1958. Salicylate and salicyl conjugates: fluorimetric estimation, biosynthesis and renal excretion in man. J. Clin. Invest. 37: 800-807.

7. von Lehmann, B., S. H. Wan, S. Riegelman, and C. Becker. 1973. Renal contribution to overall metabolism of drugs. IV. Biotransformation of salicylic acid to salicyluric acid in man. J. Pharm. Sci. 62: 1483-1486.

8. Nelson, E., M. Hanano, and G. Levy. 1966. Comparative pharmacokinetics of salicylate elimination in man and rats. J. Pharmacol. Exp. Ther. 153: 159-166.

9. Marquardt, D. W. 1966. Least squares estimation of nonlinear parameters, a computer program in Fortran IV language. IBM SHARE library, distribution No. 309401, IBM Corp., Princeton, N. J.

10. Rescigno, A., and G. Segre. 1966. Drug and Tracer Kinetics. Blaisdell, Waltham, Mass. 27-28, 93-94.

11. Gibaldi, M., R. Nagashima, and G. Levy. 1969. Relationship between drug concentration in plasma or serum and amount of drug in the body. J. Pharm. Sci. 58: 193-197.

12. Brodie, B. B., S. Udenfriend, and A. F. Coburn. 1944. Determination of salicylic acid in plasma. J. Pharmacol. Exp. Ther. 80 : 114-117.

13. Rowland, M., and S. Riegelman. 1968. Pharmacokinetics of acetylsalicylic acid and salicylic acid after intravenous administration in man. J. Pharm. Sci. 57: 1313-1319.

14. Hollister, L., and G. Levy. 1965. Some aspects of salicylate distribution and metabolism in man. J. Pharm. Sci. 54: 1126-1129.

15. Wiegand, R. G., and P. G. Sanders. 1964. Calculation of kinetic constants from blood levels of drugs. J. Pharmacol. Exp. Ther. 146: 271-275.

16. Levy, G., A. W. Vogel, and L. P. Amsel. 1969. Capacity-limited salicylurate formation during prolonged administration of aspirin to healthy human subjects. $J$. Pharm. Sci. 58: 503-504.

17. Levy, G., L. P. Amsel, and H. C. Elliott. 1969. Kinetics of salicyluric acid elimination in man. J. Pharm. Sci. 58: $827-829$.

18. Andreasen, F. 1973. Protein binding of drugs in plasma from patients with acute renal failure. Acta Pharmacol. Toxicol. 32 : 417-429.

19 Campion, D. S. 1973. Decreased drug binding by serum albumin during renal failure. Toxicol. Appl. Pharmacol. 25: 391-397.

20. Reidenberg, M. M., and M. Affrime. 1973. Influence of disease on binding of drugs to plasma proteins. Ann. N. Y. Acad. Sci. 226: 115-126.

21. Kamath, B. L., and G. Levy. 1974. Renal contribution to drug biotransformation. J. Pharm. Sci. 63: 13421343. 